\title{
Assessing the Impact of the Oil Price Shocks on Economic Growth in Oil-Exporting Arab Countries
}

\author{
MAYIS G. GÜLALIYEV \\ Mingachevir State University, Mingachevir, AZERBAIJAN \\ RAHIMA N. NURALIYEVA \\ Azerbaijan State University of Economics (UNEC), Baku, AZERBAIJAN \\ RUHIYYA A. HUSEYNOVA \\ Mingachevir State University, Mingachevir, AZERBAIJAN \\ FIRUDIN E. HATAMOV \\ Institute of Oriental Studies of Azerbaijan National Academy of Sciences, AZERBAIJAN \\ ALIKHANLI S. YEGANA \\ Azercell Telecom LLC, Azerbaijan Cooperation University, Baku, AZERBAIJAN \\ ELVIN S. ABDULLAYEV \\ Azercell Telecom LLC, Azerbaijan State University of Economics (UNEC), Baku, AZERBAIJAN
}

\begin{abstract}
The role of oil and gas in the modern economy is undeniable. That is why oil-exported countries have a good chance to wealth. But if the economy doesn't have diversification or there is no political stability this revenue cannot become welfare for the long run. As well as the changing of oil prices doe in the world market can impact the revenues of oil-exported countries. The purpose of the research is to assessthe impact of the oil price shocks on economic growth in oil-exporting Arab countries. As a methodology, there were chosen VAR models and Granger causality tests. The practical importance of the research is to predict economic growth in other oil-exporting countries. The authors came to the conclusion that oil-price change has positive impacts on GDP growth in oil-rich Arab countries and there is the strong dependency from oil prices. The originality and scientific novelty of the research connected with this argue that oil revenues have impacts on economic growth only in economic and political stability.
\end{abstract}

Key-Words: oil-reach countries; oil price shocks; oil rent; economic growth; VAR model; Dutch syndrome

Received: July 23, 2021. Revised: December 30, 2021. Accepted: January 18, 2022. Published: January 20, 2022.

\section{Introduction}

The role of oil and gas in the modern economy is undeniable. Ensuring energy security in the world currently depends on three natural resources - oil, gas, and coal. Over the last hundred years, the extensive use of these resources has led to the rapid depletion of all three types of natural resources. The study of alternative energy sources and the increase in a technical capacity in recent decades do not yet give hope that this type of energy can completely replace hydrocarbon energy in the near future. The expansion of globalization, population growth and the gradual rise in living standards around the world are increasing the demand for energy. The unequal distribution of hydrocarbon energy on Earth also exacerbates international conflicts. Oil-rich countries tend to take advantage of this absolute wealth and sell it at a higher price. Countries with small oil and gas reserves but large economic and military power are trying to use their power to dominate the world by keeping the production and transportation of hydrocarbon resources in their hands.

Since we have studied the role of oil and gas in the modern economy in detail in the previous paragraph, we will only note here that oil and gas as a commodity benefit both producers and consumers. Our research examines the benefits it can bring to the manufacturer. The unequal distribution of natural resources in all geographical areas and serious inequality have created absolute advantages for countries with these resources. Oil and gasproducing countries earn money by exporting it to 
other countries. In most cases, such revenues are high and long-term. So do not include the strongest oil producers in the world for the last 50 years. The Middle East, Russia, Venezuela, Colombia, Nigeria, Norway, and other countries have maintained their positions in the world market as major exporters. The United States, a major oil producer, remains the world's largest consumer. Azerbaijan is one of the main oil reserves in the twentieth century. After gaining independence in the Soviet Union, the country was able to conclude direct contracts for oil production. These oil-producing countries, with the exception of Norway, are not highly developed. However, for most of these countries, oil export revenues provided favorable financial opportunities for economic and socio-economic development.

\section{Problem Formulation}

The main source of controversy about the impact of the oil economy on the economy is the inefficient use of revenues. In fact, the availability of any natural resources, such as water, quality soil, gold, or any precious metal, as well as oil and gas sources, is a great blessing that nature has given to people and the country. Proper use of this blessing should only bring happiness and prosperity to people. The inflow of oil and gas revenues into the country can serve to solve other problems, especially social problems. Using these revenues, the country can develop economic and social infrastructure, develop science and technology by attracting highly qualified personnel to the country, and so on. In all cases, the additional income of natural resources creates new economic opportunities.

Unfortunately, in reality, very few countries use this opportunity effectively. For some countries, oil and gas reserves have played an important role in eradicating poverty (for example, the United Arab Emirates, Qatar, Kuwait), and in a short period of time the quality of life in these countries has improved. However, in some countries (for example, Iraq, Libya), these revenues have exacerbated the conflict in the country and even led to civil war. A comparative analysis of the level of development of oil-exporting countries with countries without oil and gas reserves suggests that the existence of oil revenues is not sufficient for sustainable socio-economic development. The dependence of the country's economy on oil and gas revenues creates serious problems for the independent development of other sectors of the economy. Even in some countries, the negative impact of high oil and gas revenues on the development of other sectors has attracted the attention of economists. This phenomenon, known as the "Dutch syndrome" in the economic literature, has been studied in various countries.

Purpose: Assessing the impact of multiple changes in world oil prices on economic growth in some oilrich developing countries

\subsection{Impacts of Oil Price Shocks on Economic Growth (Literature Review)}

The essence of the "Dutch syndrome" is that the rapid development of any sector of the economy has a negative impact on the development of other sectors (Corden and Neary, 1982) [1]. It envisages the weakening of agriculture and the processing industry as a result of the rapid development of the natural resources sector, such as oil or gas production or gold production, and so on. This problem was studied in 1982 by Max Corden and Peter Neary as a classical economic model. According to this model, the "Dutch syndrome" is distinguished by three main features: 1) The rapid development of one sector in the country compared to other sectors creates an advantage for this sector in exports; 2) The price of the national currency is rising; 3) Other sectors lose their competitiveness compared to the fast-growing sector (Corden and Neary, 1982) [1].

The mechanism of the impact of oil and gas production on the economy is realized through the revenues coming to the country. Such revenues mainly depend on both the volume of production and world market prices. That is why, in most cases, oil-exporting countries use their monopolistic positions to try to reach an agreement not to increase production in order to keep prices from falling. Given the dependence of revenues on production and prices, economic research has focused more on the dependence of macroeconomic indicators on prices. Because price, as a more flexible indicator, affects both the volume of production and demand.

There are many studies in the economic literature on the effects of oil prices on the economy. The vast majority of these studies have focused on the effects of oil prices on the economies of oil-importing countries, especially developed countries. Changes in oil prices affect the production process by changing the volume of students in those countries. As we are interested in the impact of oil price fluctuations on world markets and possible impacts on oil-exporting countries through changes in world oil prices, we will focus on the amount of currency entering the country as channels for the impact of oil prices on such economies. These revenues affect the economic policy of the country through various mechanisms. For example, transferring to the budget increases public spending. As the supply of foreign currency increases, so does the demand for the 
national currency, and so on. These problems have been extensively studied by different researchers in different countries.

In a study conducted by Alekhina, V. and $\mathrm{N}$. Yoshino (2018), the effects of oil prices on the macroeconomic indicators of the exporting country were studied by the vector autoregression (VAR) method. The study included non-OPEC oil exporters. Revenues from oil exports in these countries have a significant share in the country's total exports and total revenues. The study shows that changes in oil prices have a significant impact on the country's GDP, consumer price index, interest rates, and exchange rates. In this study, price fluctuations were conducted for the period 1993-2016. The novelty of the model used in the study is that this model also includes a monetary indicator. According to the authors, this is due to the fact that the impact of oil revenues on the economy of exporting countries is also through monetary channels. An increase in the country's oil revenues as net prices rise can also reduce interest rates and inflation, and strengthen the national currency against the dollar. However, the decline in the world price of the net may accelerate the opposite process.

The relationship between oil production and exports and macroeconomic indicators in the case of Algeria was studied by Heidarian and Green (1989) [2]. Given the fact that oil production and exports are under state control, researchers view oil exports as a potential for economic development. Methodologically, the study used 12 equations according to the Keynesian econometric model. These equations used the least-squares method, high R-squares, significant t-statistics, and the DurbinWatson test to ensure reliability. The results of the study show that both before and after nationalization, various economic sectors are highly dependent on oil revenues. Unless other conditions change, the increase in oil exports increases the volume of imports of luxury goods and domestic consumption. The elasticity of import volumes and domestic consumption is high. Inelastic growth is typical of domestic investment. Researchers attribute the increase in oil exports to the country's current policy of failing to achieve the goal of diversification, modernization, and industrialization. The methodology used by Alekhina, V. and N. Yoshino, (2018) takes into account GDP growth rate, consumer price inflation (CPI), the exchange rate of the national currency against the US dollar, and interest rates in the country, such as the price of branded oil and macroeconomic indicators. Using the structural VAR model, the interrelationships and cause-and-effect relationships between the indicators were investigated. To determine the relationship between world oil prices and macroeconomic indicators, Alekhina, V. and N. Yoshino, (2018) used the following VAR model:

$$
B_{0} * X_{t}=\beta+\sum_{i=1}^{j} B_{i} * X_{t-i}+u_{t}
$$

Here $\mathrm{X}_{\mathrm{t}}=\left(\mathrm{X}_{1 \mathrm{t}}, \mathrm{X}_{2 \mathrm{t}} \ldots \mathrm{X}_{\mathrm{nt}}\right)$ is a vector of endogenous variables of size $n \times 1 . \beta=(\beta 1, \beta 2 \ldots$ $\beta n$ ) is a vector coefficient of size $n \times 1$. $B_{i} n \times n$ is a coefficient matrix. $X_{t-i}$ is the lag operator. $j$ is the size of the lags. And $u_{t}=\left(u_{1 t}, u_{2 t} \ldots u_{n t}\right) n \times 1$ is a non-correlated structural innovation of size $\mathrm{n} \times 1$. [3]

This problem was studied by Al-Moneef (2006) on the example of oil-exporting Arab countries. This study takes into account the direct effects of the oil sector on the economy, as well as indirect effects. One of such indirect effects is the export effects of the oil sector on the non-oil sector. The study identified five links between the oil sector in the Arab world and other economic sectors, and four links between the oil sector and the non-oil export group. The author claims that the relationship between the oil sector and other sectors of the economy varies from country to country, depending on the economic situation in the country.

Al-Moneef (2006) [4] distinguishes between the change in oil prices at the beginning of the $21 \mathrm{st}$ century and the nature of price changes in the last century and believes that the price changes in 1974 and 1980 were leaps and gradual changes in the early 21 st century. He claims that the presence of large oil and gas reserves in the region and large oil exports over the past 30 years compared to other regions have had a serious impact on the economy and social life of Arab countries. As the economic impact in these countries is mainly through fiscal channels, public spending has increased and the non-oil sector has lost its competitiveness. In these countries, government intervention in the economy is high because the main costs and investments are made by the state. Al-Moneef (2006) argues that the large revenues of oil-exporting Arab countries also affect the economies of neighboring countries that do not export oil. Thus, the high living conditions of the country's population increase the flow of tourism from the country, the arrival of migrant workers in the country increases remittances from the country, and so on.

The impact of oil and gas revenues on the Iranian economy is reflected in a study by Dreger and Rahmani (2014) [5]. The study examines the impact of oil and gas revenues on the economy using panel analysis of Iran and other Gulf countries. For these countries, there is a co-integration between oil revenues, GDP and investment. However, research shows that the co-integration between GDP and 
investment and oil revenues in Iran is different than in other Gulf countries. The indicator that characterizes oil revenues in this country behaves as a weak exogenous variable. However, both indicators react to the imbalance of the country's economy. The elasticity of oil revenues for the Gulf countries is higher than in Iran. On the other hand, investments in Iran do not react to changes in oil revenues in the long run. According to the neoclassical theory, oil revenues should have a positive effect on GDP growth per capita, as they increase investment activity. As in other oilexporting countries, oil and gas revenues in Iran have an exceptional role in the development of the country's economy and the solution of socioeconomic problems.

Khalid and Azrai (2014) [6] studied this problem in the example of the Sudanese economy. The study examines the dependence of the Sudanese economy on oil revenues between 2000 and 2012. The regression analysis examines the cause-and-effect relationship between oil revenues and value-added in the service sector. The results show that there is a positive relationship between oil revenues and value-added in the service sector. In the Sudanese economy for the period 2000-2012, 78.8\% of GDP is provided by oil revenues. Analyzes show that a $1 \%$ change in oil revenues changes the value-added in the service sector by $0.0246 \%$. The research used the simple linear regression method (SLRM) and the smallest squares method (OLS) as the methodological basis. An extended Dickey-Fuller (ADF) test and the Phillips-Perron single root method were used to test the time series of both oil revenues and GDP generated from the service sector. It turned out that both of these indicators are non-stationary time series. Only in the second-order change was it determined that the time series were stationary, ie, I (1) degree cointegration. In order to determine the cause-and-effect relationship between these indicators, Johansen's cointegration test was used and it was determined that there is a cause-andeffect relationship between these two indicators.

Olayungbo and Adediran (2017) [7] studied the effects of oil revenues and institutional quality on economic growth between 1984 and 2014 in the case of Nigeria. The study used the ARDL method to determine the balance between long-term oil revenues, institutional quality and economic growth. The corruption index was used as a quantitative indicator of institutional quality. The analysis shows that institutional quality has a positive effect on economic growth in the short term, but there is a negative relationship between these indicators in the long term. The study also shows that oil revenues have a positive impact on economic growth in the short term and a negative impact in the long run.
This result proves that oil revenues in Nigeria have created the "Dutch syndrome". Impulse response analyzes based on the data obtained also confirm the results obtained by the ARDL method. Based on the results of the study, the authors believe that institutional quality plays an important role in the relationship between oil revenues and economic growth, and conclude that if anti-corruption measures are taken, the positive impact of oil revenues on economic growth can be ensured in the long run.

The impact of the Nigerian oil sector on the economy has also been studied by Idowu (2016) [8]. The study, which covers 1981-2015, provides a comparative analysis of the impact of oil and nonoil exports on the Nigerian economy. The main evaluation methods used in this study were the extended Dickey-Fuller test, the Johansen cointegration test, the Granger causality test, the impulse response function, and the variance decomposition method. The cointegration test confirms that GDP, oil, and non-oil exports cointegrate. The Granger test confirms that in the short run, there is a one-way causal relationship between oil exports and GDP, ie from exports to GDP. In the long run, the causal relationship between these indicators is twofold. However, in the long run, there is a one-way causal relationship between non-oil exports and GDP. The main result of the study is that the relationship between oil exports and economic growth in Nigeria is negative, but the relationship between the non-oil sector and economic growth is positive.

Humbatova and Hajiyev (2019) [9] studied the role of oil revenues in the Azerbaijani economy in comparison with its role in the world economy. The study used an error correction model (ECM) and reliability was assessed using fully modified Fully Modified OLS, Dynamic Minimum Squares (DOLS), and Conical Cointegration Regression (CCR) methods. The co-integration relationship between the variables was tested by Engel-Granger and Phillips-Ouliaris co-integration tests. The uniformity of time series has been tested by Augmented Dickey-Fuller (ADF), Phillips-Perron (PP), and Kwiatkowski-Phillips-Schmidt-Shin (KPSS) methods. The result is that daily oil production and consumption. On the other hand, the impact of world GDP and industrial production is much greater. In general, the impact of daily oil consumption and production, as well as world GDP and industrial production on the world oil market is declining. process, ie oil production and prices have a significant impact on macroeconomic indicators. As these countries export oil, their national currency, GDP, is strongly dependent on the oil factor. 
Humbatova and others (2019) [10] studied the dependence of GDP, national income, consumer price index, fixed assets, as well as investment on oil production and oil prices on world markets in Azerbaijan. The study identified the main factors affecting oil production, as well as the main factors that depend on oil prices by econometric methods. Regression equations covering some macroeconomic indicators related to factors affecting oil production and oil prices allow determining the dependence of the manat on the dollar and the consumer price index. The results of the study were compared with previous years and the base $(2000=100)$.

In Chad, Gadom and others (2018) [11] studied the socio-economic impacts of oil production by conducting a household survey. The main purpose of the study was to study the impact of oil revenues on welfare. The study used a multidimensional wellbeing index for households and a differentiated approach) [12]. The main result of the study is that in Chad, the regions that receive oil transfers have the highest multidimensional welfare index. Therefore, in order to ensure economic inclusion, the state should reconsider the policy of distribution of oil revenues and take into account the needs of those regions. This study also argues that the impact of oil revenues on the social sphere depends on the current institutional situation.

The study of the socio-economic effects of oil revenues is especially relevant. Because the main goal of any state is to protect the security of its citizens in all areas, including socio-economic security. Although the inflow of oil revenues into the country creates new opportunities for solving social problems, it has a serious impact on the emergence of intersectoral unemployment and income inequality in most oil-exporting countries. At first glance, the inflow of foreign currency into the country through the export of oil is formally similar to the inflow of currency into the country from the export of other commodities. However, the socio-economic effects of the former differ sharply from those of the latter. The main reason for this is most likely due to the fact that oil revenues are mainly controlled by the state and enter the real economy mainly through fiscal mechanisms. In the case of redistribution of oil revenues through fiscal mechanisms, not all social groups and households can benefit equally from oil revenues. In the case of export diversification, more groups of the population will be able to benefit from export revenues. On the other hand, such revenues are more quickly and efficiently distributed in the market because they are not managed by the state. That is why in the case of export diversification, the "Dutch syndrome" almost does not occur. The inflow of more foreign currency into the economy in a short period of time from oil and gas revenues causes the "Dutch syndrome".

According to a study by Ismail (2010) [13], a sharp increase in exports in the resource sector reduces the conversion capacity of the non-resource sector, and the economy becomes more specialized on one resource. In this case, the economy depends on this resource. Negative effects of Dutch syndrome on economic growth, in the long run, Arezki and van der Ploeg (2010) [14]; Baggio and Papyrakis (2010) [15]; Extensively studied in Mursheb and Serino (2011) [16] and other studies.

Studies on the socio-economic effects of natural resource exports show more clearly that poor revenue management can have a negative impact on well-being and the Human Development Index. In developing oil-exporting countries, poor governance and corruption are just some of the causes. A study by Daniele (2011) [17] shows that the dependence of mineral resources on export earnings has a negative impact on the Human Development Index. The inflow of oil revenues into the country also affects income inequality in the country. Although research on this issue has attracted relatively little attention to other issues, in the particular, economic growth of oil revenues, investment activity, etc., it is increasingly attracting the attention of researchers. In fact, revenues from the export of natural resources allow the state to achieve a more equitable redistribution of income through fiscal policy. However, in reality, very few developing countries are rich in natural resources. Because the oil and gas sector, which initially requires large investments, attracts the bulk of the budget and hinders the development of other sectors. At the same time, the government is still not interested in investing in the development of the non-oil sector. Thus, there are significant differences between employment-related and, as a result, employment income, directly and indirectly, related to these sectors. This problem has been studied by Fum və Hodler (2010) [18], Parcero və Papyrakis, (2016) [19], Dizaji S.F., (2016) [20], Farzanegan və Krieger (2017) [21], and others.

Farzanegan and Krieger (2017) examine how the level of inequality in Iran reacts to the positive shocks of oil rents in the post-sanctions period for the period 1973-2012, concluding that a 10\% increase in oil rents per capita increases long-term inequality. Increases by $1.1 \%$. The study used a vector autoregression method based on the impulse response function. Changes in inequality over a period of up to 4 years $(\operatorname{lag}=[1 ; 4])$ after a positive shock of oil rents were analyzed by the ARDL method.

The most controversial point about the economic and socio-economic effects of oil revenues is the 
long-term impact of these revenues on welfare. Because in the short term, oil revenues can directly or indirectly have a positive impact on people's living conditions. The country receives investments to expand oil production, and the impact of these investments is not only directly reflected in the oil and gas industry but also indirectly in the service sector or oil-related industries. There is an increase in household incomes associated with these sectors. Spending a portion of oil revenues from oil and gas exports on social benefits, education, health services, cultural and sports activities, defense, infrastructure, etc. can have a positive impact on the living conditions of the general population. However, as such effects paralyze other sectors of the economy, the economy becomes dependent on oil revenues. The negative shock of prices in the world market is immediately reflected in the quality of life of people.

A study by Al-Sheikh, Hend and Erbas, Nuri S. (2012) [22] found that oil revenues have the potential to create public sector employment and higher wages in Saudi Arabia. In Saudi Arabia and the Persian Gulf countries, the increase in oil revenues since the 1970s, directed to infrastructure, human capital, and other social services, has enabled unprecedented economic and social development in the region. These processes have expanded trade and mutual cooperation in the region and have had a positive impact on human development. However, oil reserves have had a negative impact on the economic development of some countries in the region. The inflow of large amounts of oil revenues into the country through a single channel - the export of oil products - creates a disproportion between the growth of the country's budget and the development of the private sector. High salaries in the public and oil sectors create conditions for the influx of qualified personnel from the non-oil sector and the entry of cheap labor into the country. In this case, the unemployment rate is rising.

One of the oil-rich regions in the Middle East. Saudi Arabia, Iraq, Iran, Kuwait, Bahrain, Oman, and the
United Arab Emirates, which are located in the region, have the bulk of the world's gas and oil reserves. These countries have more than $45 \%$ of the world's proven oil reserves [23]. The Khawar field in Saudi Arabia alone and the Greater Burgan field in Kuwait have more than $25 \%$ of the world's oil reserves.

\section{Problem Solution}

Oil was discovered in the Arab world in the middle of the last century. Until the discovery of oil fields, the Arab countries were very poor. Oil production began first in Egypt, Iraq, Saudi Arabia, and Bahrain, and then in other Arab countries. Arab countries are divided into three groups based on oil and gas production. Countries that produce and export large amounts of oil. This group includes Saudi Arabia, Kuwait, the UAE, Iraq, Algeria, Libya, Qatar, Oman, and Tunisia. Algeria has significantly depleted oil reserves and its exports have declined in recent years. The second group of Arab countries is oil importers. This group includes Morocco, Mauritania, Sudan, Lebanon, Jordan, the Yemeni Arab Republic, and the People's Democratic Republic of Yemen. Some Arab countries, on the other hand, are only able to meet their own oil needs, and they do not export oil or export it in negligible quantities. This group of countries includes Syria and Egypt. These countries are also running out of oil reserves, and in the near future, these countries will have to pay for their domestic consumption through imports. Thus, only eight of the 23 Arab countries are rich in oil and can be considered oil exporters. Absolute monarchy reigns in six of the nine oil and gas-rich Arab countries. The ongoing civil war in Iraq and Libya in recent years does not allow them to recover not only their economy but also their political system. But formally, it is a parliamentary republic in these countries. Algeria also has a parliamentary republic as a form of government.

Table 1. Approved oil reserves in Arab countries (billion barrels)

\begin{tabular}{|l|c|c|c|c|}
\hline & 1998 & 2008 & 2017 & 2018 \\
\hline Saudi Arabia & 261.5 & 264.1 & 296.0 & 297.7 \\
\hline UAE & 97.8 & 97.8 & 97.8 & 97.8 \\
\hline Iraq & 112.5 & 115 & 147.2 & 147.2 \\
\hline Kuwait & 96.5 & 101.5 & 101.5 & 101.5 \\
\hline Oman & 5.4 & 5.6 & 5.4 & 5.4 \\
\hline Libya & 29.5 & 44.3 & 48.4 & 48.4 \\
\hline Qatar & 13.5 & 26.8 & 25.2 & 25.2 \\
\hline
\end{tabular}

Note: Based on BP (2020) 
The richest country in oil in the Arab world is Saudi Arabia. According to 2018 data, the country's proven oil reserves exceed 297.7 billion barrels. The annual production in this country is higher than in other Arab countries, even in the region. Saudi Arabia has produced more than 500 million tons of oil annually over the past 10 years. According to 2018 data, Saudi Arabia's daily oil production has already exceeded 11 million barrels. This is $13 \%$ of the world's total oil production. That is why the other Saudi Arabia has the ability to influence oil prices on world markets by managing its own production. Given the volume of production of other OPEC countries, OPEC is able to fully control oil prices. For comparison, in 2018, Azerbaijan's oil production amounted to 795,000 barrels per day. This means only $0.8 \%$ of world oil production. However, maintaining oil production at this level in the coming years indicates that Saudi oil will be rapidly depleted. Thus, if the daily oil production was 11 million barrels, Saudi Arabia would have fully used its reserves in 70 years at best. In other Arab countries, depletion of resources is possible more quickly.

Table 2. Dynamics of oil production in Arab countries (million tons)

\begin{tabular}{|l|r|r|r|r|r|r|r|r|r|r|r|}
\hline & 2008 & 2009 & 2010 & 2011 & 2012 & 2013 & 2014 & 2015 & 2016 & 2017 & 2018 \\
\hline Saudi Arabia & 510.0 & 459.0 & 463.3 & 522.7 & 549.2 & 538.4 & 543.8 & 568.0 & 586.7 & 559.3 & 578.3 \\
\hline UAE & 145.2 & 129.3 & 135.2 & 150.6 & 156.9 & 163.3 & 163.4 & 176.1 & 182.4 & 176.2 & 177.7 \\
\hline Iraq & 119.3 & 119.7 & 120.8 & 135.8 & 151.3 & 152.0 & 158.8 & 195.6 & 217.6 & 222.2 & 226.1 \\
\hline Kuwait & 136.0 & 120.9 & 123.2 & 140.7 & 153.8 & 151.2 & 150.0 & 148.1 & 152.5 & 144.8 & 146.8 \\
\hline Oman & 37.1 & 39.7 & 42.2 & 43.2 & 45.0 & 46.1 & 46.2 & 48.0 & 49.3 & 47.6 & 47.8 \\
\hline Libya & 88.2 & 81.7 & 84.6 & 24.3 & 72.6 & 49.4 & 24.4 & 20.5 & 19.3 & 43.8 & 47.5 \\
\hline Qatar & 64.5 & 62.4 & 70.9 & 77.7 & 82.2 & 84.2 & 83.5 & 81.2 & 81.6 & 78.5 & 78.5 \\
\hline Egypt & 34.7 & 35.3 & 35.0 & 34.6 & 34.7 & 34.4 & 35.1 & 35.4 & 33.8 & 32.2 & 32.7 \\
\hline
\end{tabular}

Note: Based on BP (2020)

The Arab countries have a significant share in the world not only in terms of oil reserves, but also in terms of gas reserves. According to BP, Qatar and Iran have the richest gas fields in the Middle East. According to BP in 2018, Qatar's gas reserves exceed 24.7 trillion cubic meters. This is $12.5 \%$ of the world's gas reserves. The presence of such a large amount of gas in the country, which has a population of only $0.037 \%$ of the world's population, has affected all sectors of its economy. The country has been producing oil since the 1940s. However, at that time, Qatar, like other Arab countries, was ruled by the United Kingdom as a poor country. In the second half of the last century, the discovery and production of large gas fields in the country, as well as the effective investment of oil and gas revenues in economic development, led to the rapid development of Qatar.

Table 3. Proven gas reserves in Arab countries (trillion cubic meters)

\begin{tabular}{|l|c|c|c|c|}
\hline & 1998 & 2008 & 2017 & 2018 \\
\hline Saudi Arabia & 5.8 & 7.1 & 5.7 & 5.9 \\
\hline UAE & 5.8 & 5.9 & 5.9 & 5.9 \\
\hline Iraq & 3.0 & 3.0 & 3.6 & 3.6 \\
\hline Kuwait & 1.4 & 1.7 & 1.7 & 1.7 \\
\hline Oman & 0.5 & 0.9 & 0.7 & 0.7 \\
\hline Libya & 1.2 & 1.5 & 1.4 & 1.4 \\
\hline Qatar & 11.3 & 26.3 & 24.7 & 24.7 \\
\hline Bahrain & 0.3 & 0.2 & 0.2 & 0.2 \\
\hline
\end{tabular}

Note: Based on BP (2020)

In recent years, Qatar has had the highest GDP per capita in the world. According to the World Bank (WB, 2020) [24], Qatar's GDP per capita has increased steadily since 1970 , from $\$ 2,756$ to $\$$ 68,800 in 2018. The level of welfare of the population in the country is high compared to other Arab countries and countries in the region, and even some developed countries. However, while Qatar's large gas reserves provide it with financial resources, declining revenues from the sale of natural resources could have serious consequences in the future. The train produced 175.5 billion cubic meters of gas in 2018. If this volume is maintained and no new reserves are discovered, then the reserves can be used for 140 years. However, it should be borne in mind that if world gas consumption is maintained at current levels and no new reserves are discovered, then these reserves 
may be depleted in a relatively short time, i.e. only 50 years. The unequal distribution of gas resources around the world and the inability of alternative energy sources to completely replace traditional energy sources may lead to future inter-country and inter-regional conflicts.

Table 4. Dynamics of gas production in Arab countries (billion cubic meters)

\begin{tabular}{|c|c|c|c|c|c|c|c|c|c|c|c|}
\hline & 2008 & 2009 & 2010 & 2011 & 2012 & 2013 & 2014 & 2015 & 2016 & 2017 & 2018 \\
\hline Saudi Arabia & 76.4 & 74.5 & 83.3 & 87.6 & 94.4 & 95.0 & 97.3 & 99.2 & 105.3 & 109.3 & 112.1 \\
\hline UAE & 49.0 & 47.6 & 50.0 & 51.0 & 52.9 & 53.2 & 52.9 & 58.7 & 60.3 & 62.0 & 64.7 \\
\hline Iraq & 6.5 & 6.9 & 7.1 & 6.3 & 6.3 & 7.1 & 7.5 & 7.3 & 9.9 & 10.1 & 13.0 \\
\hline Kuwait & 12.1 & 10.9 & 11.1 & 12.9 & 14.7 & 15.5 & 14.3 & 16.1 & 16.4 & 16.2 & 17.5 \\
\hline Oman & 24.1 & 23.9 & 25.7 & 27.1 & 28.3 & 30.8 & 29.3 & 30.7 & 31.5 & 32.3 & 36.0 \\
\hline Libya & 15.1 & 15.1 & 16.0 & 7.5 & 11.6 & 12.2 & 11.8 & 11.0 & 9.4 & 9.6 & 9.8 \\
\hline Qatar & 79.7 & 92.4 & 123.1 & 150.4 & 162.5 & 168.2 & 169.6 & 175.0 & 173.8 & 172.4 & 175.5 \\
\hline Egypt & 56.8 & 60.3 & 59.0 & 59.1 & 58.6 & 54.0 & 47.0 & 42.6 & 40.3 & 48.8 & 58.6 \\
\hline
\end{tabular}

Note: Based on BP (2020)

Although the richness of some Arab countries in oil and gas creates opportunities for their economic development, it makes their economies dependent on oil and gas revenues. According to the World Bank's estimates for 2017, Iraq (37.8\%), Libya (37.3\%), Kuwait (36.6\%), Saudi Arabia (23.1\%), and Oman $(21.8 \%)$ ranked first in terms of the share of oil rents in GDP. are in the top six. For comparison, Azerbaijan is in the top ten with $17.9 \%$. Oil rents in Arab countries average 16.4\% of GDP. Among the oil-rich Arab countries, Iraq, Libya,
Kuwait, Saudi Arabia, and Oman have almost maintained their balance over the past 20 years. Despite the decline in oil rents in these countries in 2008-2009, it rose again in subsequent years. The share of oil rents in GDP in Bahrain is not so high. At the same time, the ratio of rent to GDP in this country has not changed sharply from year to year. The sharp change in this indicator from year to year is more likely to depend on changes in oil prices on world markets. It should be noted that in these countries, both rent and GDP depend on oil prices.

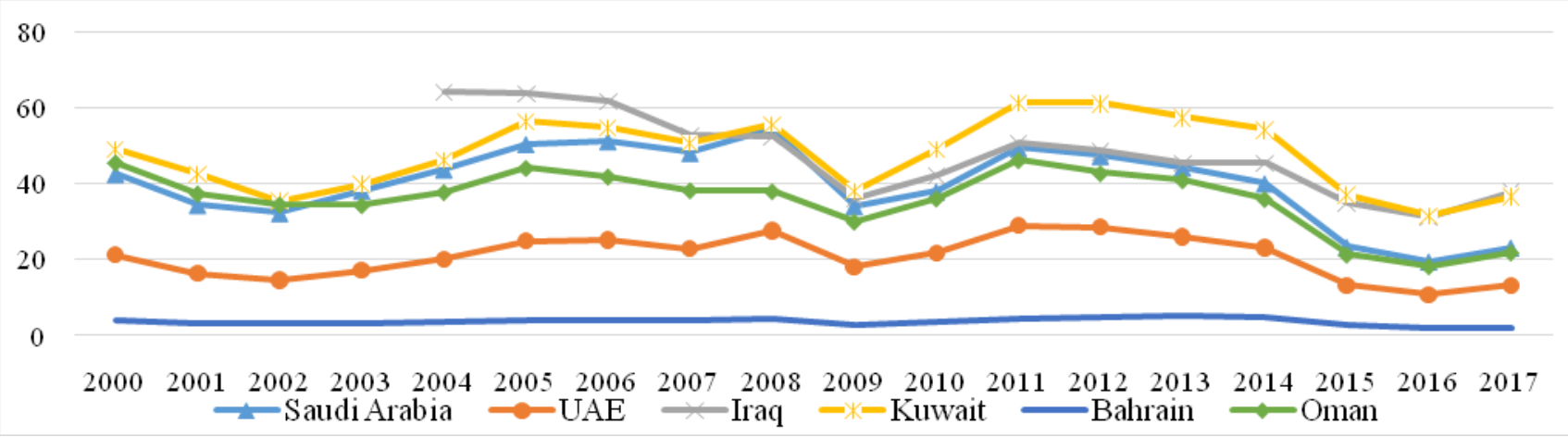

Fig. 1: Share of oil rent in GDP in some oil countries (\%)

As a result of the dependence of both rents and GDP on oil prices, per capita GDP in oil-rich Arab countries is not a function of continuous growth
(Figure 2). Almost all oil-rich Arab countries have a sharp rise and fall in GDP per capita.

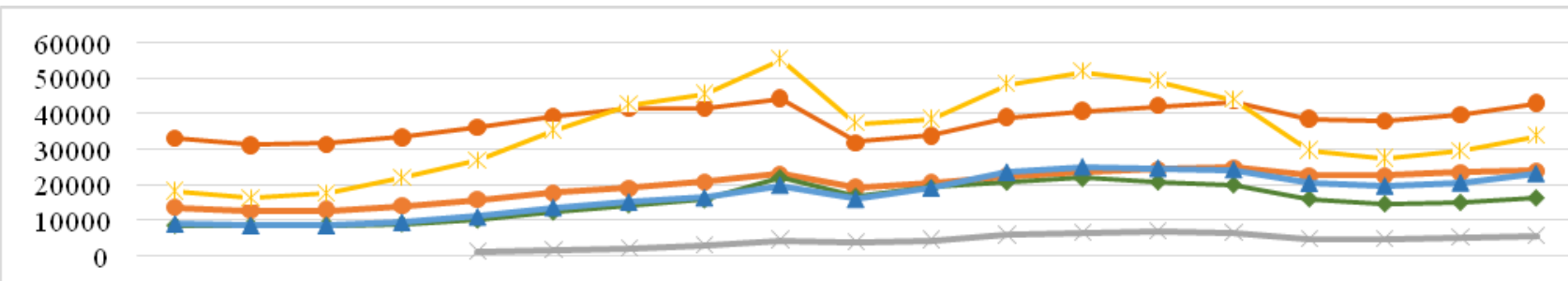

2000200120022003200420052006200720082009201020112012201320142015201620172018

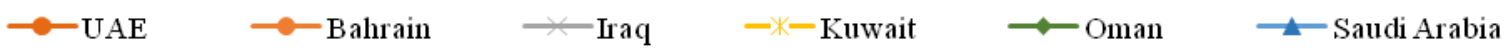


Fig. 2: GDP per capita in some oil-rich countries

\subsection{Methodology}

In the study of the macroeconomic effects of oil shocks, the impulse response function is used more with the analysis of two-time series based on the

$$
\left\{\begin{array}{c}
\mathrm{GDP}_{\mathrm{t}}=\mathrm{a}_{11}+\mathrm{a}_{12} * \mathrm{GDP}_{\mathrm{t}-1}+\mathrm{a}_{13} * \operatorname{OILP}_{\mathrm{t}-1}+\varepsilon_{\mathrm{t}} \\
\operatorname{oILP}_{\mathrm{t}}=\mathrm{a}_{21}+\mathrm{a}_{22} * \mathrm{GDP}_{\mathrm{t}-1}+\mathrm{a}_{23} * \operatorname{OILP}_{\mathrm{t}-1}+\mathrm{v}_{\mathrm{t}}
\end{array}\right.
$$

Both GDP and oil price shocks are possible here. Therefore, there is a need to compile a four-pulse response function. Four impulse response functions characterizing the effect of the shock on economic growth at the points of change of time series $\mathrm{GDP}_{\mathrm{t}}$ and OILP and the effect of oil prices at the points of change of time series GDP and OILP will be compiled. For simplicity, we will assume that there is no identification problem for connections (2). In this particular case, we will accept that economic growth depends only on itself and the lag of oil prices. This means that economic growth and oil prices are not synchronous, but dynamic. Any t-time change in oil prices is not reflected in a t-time change in economic growth. Also, the change in ttime economic growth is not felt in the t-time change in oil prices. On the other hand, we will assume that $\varepsilon_{\mathrm{t}}$ vo and $v_{\mathrm{t}}$ are independent and not indicators that correlate with each other at the same time. We will also assume that $\varepsilon_{\mathrm{t}} \sim \mathrm{N}\left(0 ; \sigma_{\text {gdp }}^{2}\right)$ vo $v_{\mathrm{t}} \sim \mathrm{N}\left(0 ; \sigma_{\text {oilp }}^{2}\right)$.

To apply the (2) VAR models, we need to check the stationary I (0) of the time series GDPt and OILP $\mathrm{P}_{\mathrm{t}}$. If the time series are not stationary, then the stationary $\mathrm{I}(0)$ of the time series $\Delta \mathrm{GDP}_{\mathrm{t}}$ and $\Delta$ OILP $_{\mathrm{t}}$ will be checked. GDPand OİLP If the time series I(0) or I(1) two-variable VAR model. We will also use this method to study the effects of the oil price shocks on economic growth in some oil-rich countries: are stationary, we will apply the VEC model and use OLS in the dependencies (2).

GDP and OILP $P_{\mathrm{t}}$ You can use the Dickey-Fuller (DF) test or the Extended Dickey-Fuller (ADF) test to check the stationarity of the time series.

In the initial approach, we assume that if $y_{t}=\rho * y_{t-1}+v_{t}$, or $y_{t}=\alpha+\rho * y_{t-1}+v_{t},|\rho|<1$ then $y_{t}$ is a stationary time series. This first-degree autoregression will be considered AR (1).

In the next approximation, we will use the DickeyFuller test ( $\alpha$ stable but not trending) to increase the accuracy of the regression relationship. That is, we will assume that

Depending on $\Delta y_{\mathrm{t}}=\alpha+\gamma * \mathrm{y}_{\mathrm{t}-1}+\mathrm{v}_{\mathrm{t}}$

If $\mathrm{H}_{0}: \rho=1 \sim \mathrm{H}_{0}: \gamma=0$, the time series $y_{\mathrm{t}}$ is not stationary.

However, if $\mathrm{H}_{1}: \rho<1 \sim \mathrm{H}_{1}: \gamma<0$ and $\tau<\tau_{c}$, then the time series $y_{t}$ is stationary

Here $\tau_{c}$ are critical values for tau statistics, $y_{t}$ is the indicator under study. The estimates proposed by R. Davidson and J.G. MacKinnon (1993) [25] and given in Table 5 will be taken as the critical values of the tau statistics during the calculations.

Table 5. Critical scores for the Dickey-Fuller test $\left(\tau_{c}\right)$

\begin{tabular}{|l|c|c|c|}
\hline & $1 \%$ & $5 \%$ & $10 \%$ \\
\hline$\Delta \mathbf{y}_{\mathbf{t}}=\boldsymbol{\gamma} * \mathbf{y}_{\mathbf{t}-\mathbf{1}}+\mathbf{v}_{\mathbf{t}}$ & -2.56 & -1.94 & -1.62 \\
\hline $\mathbf{\Delta} \mathbf{y}_{\mathbf{t}}=\boldsymbol{\alpha}+\boldsymbol{\gamma} * \mathbf{y}_{\mathbf{t}-\mathbf{1}}+\mathbf{v}_{\mathbf{t}}$ & -3.43 & -2.86 & -2.57 \\
\hline $\boldsymbol{\Delta} \mathbf{y}_{\mathbf{t}}=\boldsymbol{\alpha}+\boldsymbol{\lambda} * \mathbf{t}+\boldsymbol{\gamma} * \mathbf{y}_{\mathbf{t}-\mathbf{1}}+\mathbf{v}_{\mathbf{t}}$ & -3.96 & -3.41 & -3.13 \\
\hline Standard critical prices & -2.33 & -1.65 & -1.28 \\
\hline
\end{tabular}

Source: R.Davidson and J.G.MacKinnon (1993)

For the study, the indicators for GDP and its growth for the period 2000-2018 were obtained from the World Bank (WB, 2019) database, and the monthly data on oil prices were calculated from the website https://www.macrotrends.net and the average monthly prices were calculated.

Six oil-rich countries were taken for research. They are located in the Middle East.

\section{Empirical Calculations}

Relationship between economic growth $\left(\Delta \mathrm{GDP}_{\mathrm{it}}\right)$, economic growth rate $\left(\mathrm{GDPR}_{\mathrm{it}}\right)$ in major oilexporting countries and world oil prices $\left(\mathrm{P}_{t}\right)$ and price changes $\left(\Delta \mathrm{P}_{\mathrm{t}}\right)$

- Carrying out unit root test and stationary of oil prices' time series

First of all, let's check the stationarity of the time series OÍLP $_{t}$ on the basis of the average annual 
prices of oil on the world market. Figures 3 and 4 show the dynamics of annual changes in oil prices

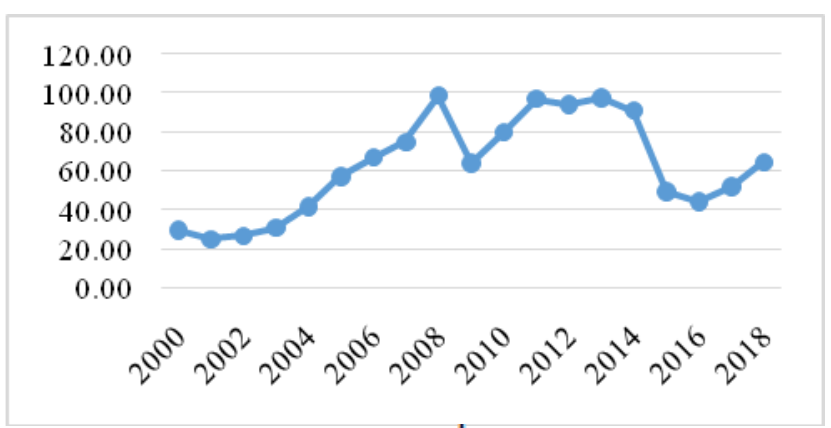

Fig. 3: Oil price dynamics (OILLP-time series)

Calculations show that the time sequence OILP $P_{t}$ is not stationary. However $\Delta \mathrm{OILP}_{\mathrm{t}}$ is stationary in the case of "none" and "intercept" and "intercept and trend", respectively. In the case of "free coefficient", ie according to the formula Dickey-Fuller according in the last 2000-2018.

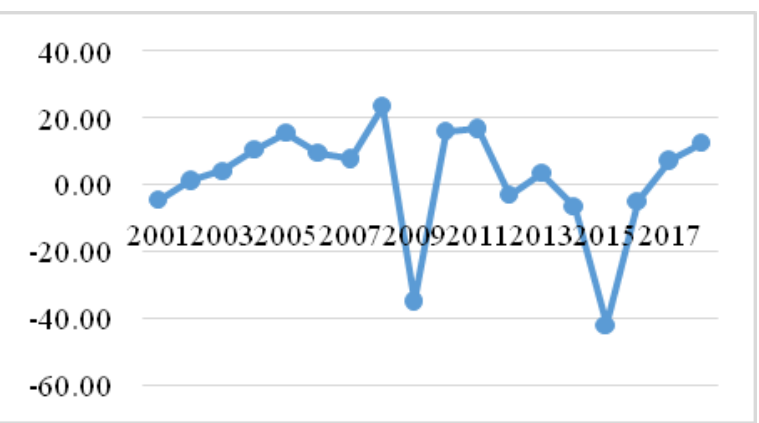

Fig. 4: Dynamics of annual changes in oil prices $\left(\Delta\right.$ OILP $P_{\mathrm{t}}$ time series)

to the formula $\Delta y_{t}=\gamma * y_{t-1}+v_{t}$, the Psignificance is smaller than other variants, and the $t-$ statistic is much lower than the critical value at -3.8 (Table 6).

Table 6. Oil prices and the stationarity of the time series of its annual changes (2000-2018)

\begin{tabular}{|l|c|c|c|c|c|c|c|}
\hline \multicolumn{2}{|l|}{ OíLP $_{\mathrm{t}}$} & \multicolumn{1}{|l|}{$\Delta$ OILP $_{\mathrm{t}}$} \\
\hline t-statistics & \multirow{2}{*}{ P-value } & \multicolumn{2}{|c|}{ intercept } & \multicolumn{2}{c|}{ none } & \multicolumn{2}{c|}{ Trend and intercept } \\
\cline { 3 - 8 } & & t-statistics & P-value & t-statistics & P-value & t-statistics & P-value \\
\hline-0.1383 & 0.6213 & -3.7631 & 0.0135 & -3.8254 & 0.0008 & -3.9676 & 0.0336 \\
\hline
\end{tabular}

Note: Calculated by the authors

- Check the stationarity of the time series of GDP and economic growth $\left(\triangle \mathrm{GDP}_{\mathrm{it}}\right)$

At the same time, it is possible to check the degree to which the time series of GDP and economic growth $\left(\Delta \mathrm{GDP}_{\mathrm{it}}\right)$, for oil-rich countries, are stationary. Calculations show that for all countries involved in the study, the time series $\mathrm{GDP}_{\text {it }}$ is not stationary the rom degree $\mathrm{I}(0)$ (Table 7 ), but is stationary under some conditions from degree $\mathrm{I}(1)$.
For example, $\Delta \mathrm{GDP}_{\mathrm{t}}$ of Saudi Arabia, the UAE, Bahrain, and Oman, is stationary from grade $\mathrm{I}(0)$ when there is "none" (there are not intercept and trend), as well as there are intercept and trend. For all countries, involved in the study, $\Delta \mathrm{GDP}_{\mathrm{t}}$ has $\mathrm{I}(0)$ degree of stationarity, when there are not intercept and trend.

Table 7. GDP and Economic Growth ( $\left.\triangle \mathrm{GDP}_{\mathrm{it}}\right)$ time series in some countries (2000-2018)

\begin{tabular}{|l|l|l|l|l|l|l|l|c|}
\hline & \multicolumn{2}{|l|}{$\mathrm{GDP}_{\text {it }}$} & \multicolumn{6}{|c|}{$\Delta \mathrm{GDP}_{\text {it }}$ (max Lag=2) } \\
\cline { 4 - 9 } & t-statistics & P-value & \multicolumn{2}{|c|}{ intercept } & \multicolumn{2}{c|}{ none } & \multicolumn{2}{c|}{ Trend and intercept } \\
\cline { 4 - 9 } & & & t-statistics & P-value & t-statistics & P-value & t-statistics & P-value \\
\hline $\begin{array}{l}\text { Saudi } \\
\text { Arabia }\end{array}$ & -0.8780 & 0.7695 & -3.3941 & 0.0272 & -2.6659 & 0.0112 & -3.3229 & 0.0980 \\
\hline UAE & -1.1157 & 0.6841 & -3.8339 & 0.0118 & -2.9641 & 0.0057 & -3.8654 & 0.0400 \\
\hline Iraq & -1.5595 & 0.4736 & -2.4809 & 0.1431 & -2.1968 & 0.0323 & -2.4556 & 0.3390 \\
\hline Kuwait & -1.7411 & 0.3945 & -3.1343 & 0.0441 & -3.0312 & 0.0049 & -3.2021 & 0.1188 \\
\hline Bahrain & 2.9808 & 0.9981 & -3.8579 & 0.0113 & -2.2541 & 0.0275 & -3.8433 & 0.0415 \\
\hline Oman & 1.2760 & 0.9417 & -4.2807 & 0.0050 & -3.5541 & 0.0015 & -4.2588 & 0.0203 \\
\hline
\end{tabular}

Note: Calculated by the authors

Calculation of regression dependence of $\triangle \mathrm{GDP}_{\mathrm{t}}$ of the Arab countries on $\triangle$ OILP $P_{t}$ by (2)

$$
\Delta \mathrm{GDP}_{\mathrm{it}}=\mathrm{a}_{11}+\mathrm{a}_{12} * \Delta \mathrm{OILP}_{\mathrm{it}}+\varepsilon_{\mathrm{t}}
$$

show that, dependence of $\triangle G P_{t}$ on $\Delta O$ ILPP $_{\mathrm{t}}$ is strong (Table 8). 
Table 8. Regression dependence of $\Delta \mathrm{GDP}_{\mathrm{t}}$ on $\Delta \mathrm{OILP}_{\mathrm{t}}$ in oil-rich countries

\begin{tabular}{|c|c|c|c|c|c|c|}
\hline & Saudi Arabia & UAE & Iraq & Kuwait & Bahrain & Oman \\
\hline$a_{11}$ & $2.66 \mathrm{E}+10$ & $1.38 \mathrm{E}+10$ & $1.13 \mathrm{E}+11$ & $3.32 \mathrm{E}+09$ & $1.4 \mathrm{E}+09$ & $2.54 \mathrm{E}+09$ \\
\hline$a_{12}$ & $3.42 \mathrm{E}+09$ & $1.74 \mathrm{E}+09$ & $1.28 \mathrm{E}+10$ & $1.24 \mathrm{E}+09$ & $1.02 \mathrm{E}+08$ & $4.03 \mathrm{E}+08$ \\
\hline $\mathrm{SE}\left(\mathrm{a}_{11}\right)$ & $6.03 \mathrm{E}+09$ & $2.47 \mathrm{E}+09$ & $3.20 \mathrm{E} 10$ & $1.86 \mathrm{E}+09$ & $1.48 \mathrm{E}+08$ & $7.66 \mathrm{E}+08$ \\
\hline $\mathrm{SE}\left(\Delta O \mathrm{OI}_{\mathrm{L}} \mathrm{P}_{\mathrm{t}}\right)$ & $3.65 \mathrm{E}+08$ & $1.5 \mathrm{E}+08$ & $1.73 \mathrm{E} 9$ & $1.13 \mathrm{E}+08$ & 8921056 & 46320209 \\
\hline t-stat $\left(a_{11}\right)$ & 4.4029 & 5.596816 & 3.5345 & 1.7796 & 9.4682 & 3.3156 \\
\hline t-stat $\left(\Delta\right.$ OILP $\left._{t}\right)$ & 9.3860 & 11.6508 & 7.4001 & 11.0238 & 11.3799 & 8.7102 \\
\hline Probability $\left(\mathrm{a}_{11}\right)$ & 0.0004 & 0.0000 & 0.0041 & 0.0941 & 0.0000 & 0.0044 \\
\hline Probability $(\Delta \mathrm{OILP})$ & 0.0000 & 0.0000 & 0.0000 & 0.0000 & 0.0000 & 0.0000 \\
\hline $\mathrm{R}^{2}$ & 0.8463 & 0.8945 & 0.8202 & 0.8836 & 0.8900 & 0.8258 \\
\hline F-significancy & 0.0000 & 0.0000 & 0.0000 & 0.0000 & 0.0000 & 0.0000 \\
\hline
\end{tabular}

Note: Calculated by the authors

It should be noted that oil-rich countries are members of OPEC and these countries have the ability to influence world oil prices. Therefore, it can be considered that in addition to the impact of oil prices on GDP in these countries, there is also the opposite effect, i.e. the cause-and-effect (Granger causality) of GDP on oil prices. However, the calculations show that in the example of the countries involved in the study, the indicators $\Delta \mathrm{GDP}_{\mathrm{t}}$ and $\triangle \mathrm{OILP}_{\mathrm{t}}$ do not have a Granger causality on each other, and the hypothesis $\mathrm{H}_{0}$ are provided in both directions (Table 9). The lags during the assessments based on the VAR model, have been selected by the Akaike criterion, Schwarz information criterion and Hannan-Quinn information criterion, and lag $=0$.

Table 8. Regression dependence of $\Delta \mathrm{GDP}_{\mathrm{t}}$ on $\triangle O$ OILP $P_{\mathrm{t}}$ in oil-rich countries

\begin{tabular}{|l|c|c|}
\hline & $\Delta \mathrm{GDP}_{\mathbf{t}} \rightarrow \Delta$ OILP & $\Delta$ OILP $_{\mathbf{t}} \rightarrow \Delta \mathrm{GDP}_{\mathbf{t}}$ \\
\hline Saudi Arabia & $\mathrm{H}_{0}$ & $\mathrm{H}_{0}$ \\
\hline UAE & $\mathrm{H}_{0}$ & $\mathrm{H}_{0}$ \\
\hline Iraq & $\mathrm{H}_{0}$ & $\mathrm{H}_{0}$ \\
\hline Kuwait & $\mathrm{H}_{0}$ & $\mathrm{H}_{0}$ \\
\hline Bahrain & $\mathrm{H}_{0}$ & $\mathrm{H}_{0}$ \\
\hline Oman & $\mathrm{H}_{0}$ & $\mathrm{H}_{0}$ \\
\hline
\end{tabular}

Note: Calculated by the authors

\section{Conclusion}

Thus, the assessments of the dependence of GDP changing of the six 6 oil-rich Arab countries on world oil prices' changing by VAR models and Granger causality tests allow drawing interesting conclusions. Thus, the change in world oil prices can not be considered a cause of change in GDP in any of these countries in the sense of Granger causality. As well as there is no reverse causal relationship between these variables. That is, although these countries are OPEC countries, changes in the GDP of these countries can not be considered a cause for changes in world oil prices. However, for each of these countries, it can be argued that rising oil prices have a positive impact on their GDP growth. However, these effects are not Granger cause and effects.

\section{References:}

[1]W. Max Corden and J. Peter Neary, Booming Sector and De-Industrialisation in a Small Open Economy. The Economic Journal, Vol. 92, No. 368 1982, pp. 825-848.

[2] Jamshid Heidarian and Rodney D. Green, The impact of oil-export dependency on a developing country The case of Algeria. Energy Economics, October 1989, pp. 247-261.

[3] Alekhina, V. and N. Yoshino, Impact of World Oil Prices on an Energy Exporting Economy Including Monetary Policy. Tokyo: Asian Development Bank Institute. ADBI Working Paper 828, March 2018, pp. 19. https://www.adb.org/publications/impactworld-oil-prices-energy-exporting-economyincluding-monetary-policy

[4] Majid Al-Moneef, The Contribution of the Oil Sector to Arab Economic Development. Roundtable Partnership for Arab Development: A Window of Opportunity held at OFID on May 5, 2006, pp. 48.

[5] Dreger, Christian; Rahmani, Teymur, The Impact of Oil Revenues on the Iranian Economy and the Gulf States, IZA Discussion Papers, (IZA), Bonn, No. 8079, 2014, pp.48.

[6]Khalid Hassan, Azrai Abdullah, Effect of Oil Revenue and the Sudan Economy: Econometric Model for Services Sector GDP. Global Conference on Business \& Social Science2014, GCBSS-2014, 15th \& 16th December, 
Kuala Lumpur Procedia - Social and Behavioral Sciences 172, 2015, pp.223 - 229.

[7]D. Oluseun Olayungbo \& Kazeem A. Adediran, Effects of Oil Revenue and Institutional Quality on Economic Growth with an ARDL Approach, Energy and Policy Research, 10 Mart 2017, pp.44-54.

[8] Idowu Raheem, Analysis of the effects of oil and non-oil export on economic growth in Nigeria. Hal open science, 25 Nov., 2016, pp. 15.

[9] Sugra Ingilab Humbatova and Natig Qadim-Oglu Hajiyev, Oil Factor in Economic Development. Energies, 12(28), 1573, 2019. pp. 40.

[10] Sugra İngilab Qizi Humbatova, Azer Islam Ogli Garayev, Sabuhi Mileddin Ogli Tanriverdiev, Natig Qadim-Ogli Hajiyev. Analysis of the oil, price and currency factor of economic growth in Azerbaijan. Entrepreneurship and sustainability issues, Volume 6 Number 3, 2019, pp. 1335- 1353.

[11] Gadom Djal Gadom, Armand Mboutchouang Kountchou and Abdelkrim Araar, The impact of oil revenues on wellbeing in Chad. Environment and Development Economics, 23, 2018, pp.591-613.

[12] Abadie, A., Semiparametric difference-indifferences estimators, Review of Economic Studies, 72 (1), 2005, pp.1-19.

[13] Ismail, K., The Structural Manifestation of the Dutch Disease: The Case of Oil Exporting Countries, International Monetary Fund. No. w/10/102, 2010, pp.37

[14] Arezki, R. and van der Ploeg, F., Trade policies, institutions and the natural resource curse. Applied Economics Letters, 17, 2010, pp. 1443-1451.

[15] Baggio, J. and Papyrakis, E., Ethnic diversity, property rights, and natural resources. Developing Economies, 48. 2010, pp.473-495.

[16] Murshed, S.Y. and Serino, L.A., The pattern of specialization and economic growth: The resource curse hypothesis revisited. Structural Change and Economic Dynamics, 22, 2011, pp. 151-161.

[17] Daniele, V., Natural resources and the quality of economic development. Journal of Development Studies, 47, 2011, pp.545-573.

[18] Fum, R.M. and Hodler, R., Natural resources and income inequality: The role of ethnic divisions. Economics Letters, 107, 210, pp.360363.

[19] Osiris J.Parcero, Income Inequality and the Oil Resource Curse. Resource and Energy Economics. Volume 45, August 2016, pp.159177.

[20] Dizaji S.F., Economic Welfare and Inequality in Iran, Palgrave Macmillan, 2016.
[21] Farzanegan, Mohammad Reza; Krieger, Tim, The response of income inequality to positive oil rents shocks in Iran: Implications for the post-sanction period, Diskussionsbeiträge, No. 04, 2017, pp. 33.

[22] Al-Sheikh, Hend and Erbas, Nuri S., The Oil Curse and Labor Markets: The Case of Saudi Arabia, Economic Research Forum, Working Paper No.697, 2012, p.31.

[23] BP Statistical Review of World Energy 2019, pp.64.

https://www.bp.com/content/dam/bp/businesssites/en/global/corporate/pdfs/energyeconomics/statistical-review/bp-stats-review2019-full-report.pdf

[24] GDP per capita (current US\$), World Bank, 2020.

https://data.worldbank.org/indicator/NY.GDP.P CAP.CD

[25] Davidson R. and MacKinnon J.G., Estimation and İnference in Econometrics, New York: Oxford University Press, 1993, p. 708.

Contribution of Individual Authors to the Creation of a Scientific Article (Ghostwriting Policy)

data curation and resources Firudin Hatamov; formal analysis, Rahima Nuraliyeva; investigation, Mayis Gulaliyev; methodology, Ruhiyya Huseynova; literature review Alikhanli Yegana and Elvin Abdullayev

Sources of Funding for Research Presented in a Scientific Article or Scientific Article Itself This investigation was investigated by the Science Development Foundation under the Prezident of the Republic of Azerbaijan. Grant № EIF-ETL-20202(36)-16/08/1-M-08

Creative Commons Attribution License 4.0 (Attribution 4.0 International, CC BY 4.0)

This article is published under the terms of the Creative Commons Attribution License 4.0 https://creativecommons.org/licenses/by/4.0/deed.en $\underline{\text { US }}$ 